\title{
Tipping fee determination to support the waste to energy concept at the city of Depok, Indonesia
}

\author{
Farizal $^{l,{ }^{*} \text { and Ekky Tammarar }}{ }^{l}$ \\ ${ }^{1}$ Department of Industrial Engineering, Faculty of Engineering, Universitas Indonesia, \\ Depok 16424. \\ Tel: (021) 78888805;Fax: (021) 78885656 \\ Email: *farizal@eng.ui.ac.id
}

\begin{abstract}
This study determines the tipping fee of municipal solid waste in the city of Depok. Two methods used to determine the fee were the income and outcome approach, and the limited resource approach. Two conditions were assumed (i.e., waste management and landfill gas bioreactor availability). From the results, the ideal tipping fee was 97,704 IDR/tonne and the application of a landfill gas reactor could boost income, thus reduced the amount of the fee collected, especially in the early years of the landfill bioreactor in operation. The fees were 40,032 and 63,337 IDR/tonne for scenario 1 and 2, respectively.
\end{abstract}

\section{Introduction}

Currently, municipal solid waste (MSW) in Indonesia is a complex problem. Based on the report by the Ministry of Environment in 2012, Indonesia's population produced an average of $2.5 \mathrm{~L}$ of waste per day. This number is equal to 625 million L of waste per day based on the calculated from the total population. Furthermore, the amount of garbage produced in the last 3 years increased exponentially. The volume of waste in 2000 reached 200,000 tonnes/day and in 2012 reached 490,000 tonnes/day or 178,580,000 tonnes/year. From the total waste, $50 \%$ of them are MSW. Another issue is MSW is not entirely well managed. Only $24.5 \%$ of the waste are treated properly, i.e., collected and dumped to landfills [1].

The city of Depok also shares a similar problem of MSW as the problem generally occurs in many cities in Indonesia. Waste generation in Depok in 2012 amounted to 4,534 $\mathrm{m}^{3} /$ day [2] and increased by $88.21 \%$ of the total waste generation in 2007 , which was 2,409 $\mathrm{m}^{3} /$ day [3]. The level of MSW management services in Depok only reached 54.04\% and the method of handling waste in Cipayung controlled landfill is not in accordance with the guidelines by the Ministry of Environment. The guidelines direct the handling of MSW with sanitary landfill. As MSW practice has not yet reached the level of good waste management, costs have increased. In 2006, the budget for waste management in Depok reached 7,232,329,000 IDR and the budget increased to 9,588,734,350 IDR in 2010 [3]. This cost increment certainly puts a burden on the city of Depok's budget. The city has an option to charge payment for the services they provide. 
According to the City of Depok's Regional Regulation No. 5of 2012, tipping fee is defined as the fees collected by the government for the waste services provided. The realisation of Depok tipping fee collection in 2001-2005 was up to $100 \%$ [3]. With the waste handled in 2006 reached $34.03 \%$, the tipping fee only reached $23.18 \%$ of the total budget of waste management. If the fee needs to cover the operational cost, then the realisation of tipping fee should cover all the costs of MSW management. Compared toother city tipping fees, the fee in Depok, which is 6,488 IDR/tonne, is lower than some other cities such as Semarang (20,462 IDR/tonne), Bogor (16,314 IDR/tonne), and Palembang(16,309 IDR/tonne). In Semarang and Bogor, with higher tipping fees than Depok, their MSW service level is also better. Semarang has a service level that reaches $75 \%$ whereas Bogor has the service level of $70 \%$.

Is the current MSW tipping fee in Depok too low so that it could not cover the total cost of waste management? Therefore, the purpose of this study is to provide an alternative way to determine the fee that can cover the entire cost of MSW management.

\section{Literature review}

\subsection{Waste and waste management}

In general, waste is defined as a material that no longer has any use value and existence value, or a material that is no longer desired. Meanwhile, according to Law No. 18 of 2008 on Waste Management, waste is a leftover from daily activities of human and/or natural processes in the solid form.

By referring to Law No. 18 of 2008, it is mentioned that the original source of waste is any person and/or as a result of natural processes that produce waste. Waste piles are waste volume or waste weight produced from various types of waste (e.g., residential, commercial, office, industrial, institutional, services, and estates) in a certain area per unit time. A source of waste is mainly from residential and traditional markets. Market wastes are majority $(95 \%)$ organics such as vegetables, fruits, fishes, and others. These wastes are easier to handle and can be decomposed by microbes. Meanwhile, MSW is generally very diverse but commonly consists of around $75 \%$ organic waste [4].

Waste management is a systematic activity that includes a comprehensive and continuous planning, reduction, and waste handling. Waste management aims to improve public health and environmental quality and makes waste as a resource. Functional elements of an integrated waste management system include a source of waste generation and source processing, collection, transportation, treatment, and final disposal [5].

\subsection{Landfill gas bioreactor}

A landfill gas bioreactor is a plant that can generate power, mostly electricity by utilising waste, both organic and inorganic wastes, as its feedstock. The principle is to exploit methane gas generated from decayed waste into fuel through a gas engine to generate electricity. A landfill gas reactor system consists of a collection system, a treatment system, electricity generation, and leachate evaporation. The collection system is the process of collecting landfill gas (LFG) derived from solid waste, which is described in the landfill as anaerobic (vacuum). A typical landfill plant is shown in Figure 1. 


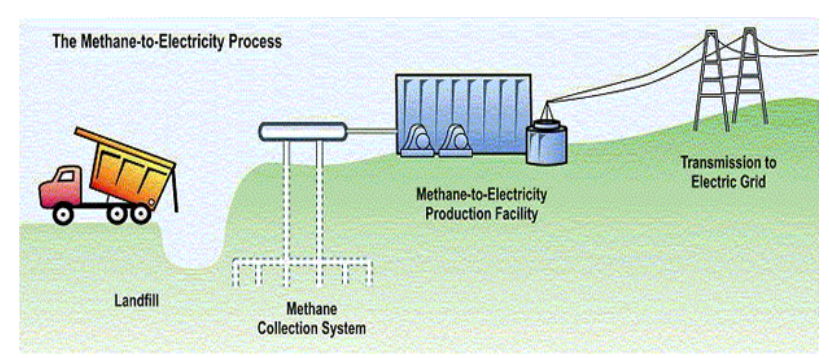

Fig.1. An illustration of a landfill gas plant [6].

\subsection{Methane estimation model}

Quantifying methane emission from a landfill is important in order to better estimate the amount of electricity generated. In the United States, the Environmental Protection Agency (US EPA) used LandGem to determine the amount of methane. This model is acknowledged as the best available approach. Many countries in Asia such as India and Thailand used this model to calculate methane gas generation. The latest version of LandGem is LandGem 3.02, which was launched in 2005. The formula of LandGem 3.02 is as follows:

$$
Q C H 4=\sum_{i=1}^{n} \sum_{j=0.1}^{1} k L_{0}\left(\frac{M i}{10}\right)\left(e^{-k t i j}\right.
$$

$$
\begin{array}{ll}
\mathrm{Q}_{\mathrm{CH} 4} & =\text { Estimated methane generation flow rate }\left(\mathrm{m}^{3}\right) \\
\mathrm{i} & =1 \text {-year time increment } \\
\mathrm{n} & =\text { (Year of the calculation) -(Initial year of waste acceptance) } \\
\mathrm{j} & =0.1 \text {-year time increment } \\
\mathrm{k} & =\text { Methane generation rate }(1 / \text { year) } \\
\mathrm{L}_{\mathrm{o}} & =\text { Potential methane generation capacity }\left(\mathrm{m}^{3} /\right. \text { tonne) } \\
\mathrm{M}_{\mathrm{i}} & =\text { Mass of solid waste disposed in the } \mathrm{i}^{\text {th }} \text { year }(\text { tonne }) \\
\mathrm{T}_{\mathrm{ij}} & =\text { Age of } \mathrm{j}^{\text {th }} \text { section of waste mass disposed in the } \mathrm{i}^{\text {th }} \text { year (decimal years) }
\end{array}
$$

\subsection{Waste management economic instrument}

Several options can be used to finance a waste management system such as fees, deposits, and subsidies [7].

Usage fees may be charged to cover the cost of transportation and disposal of garbage. The use of such tariffs can further be categorised into 3 components: user fee, discharge fee, and disposal fee. User fee is charged to cover the cost of waste management. The calculations of these fees are based on the total cost of management with the exclusion of the social costs of negative impacts on environmental quality. User fee is the fee charged for disposal in landfills, whereas disposal fee is sometimes referred to as the tipping fee. Largely, discharge fees are usually calculated according to the weight of the waste disposed.

In the deposit system, the purpose of the system is to prevent pollution and improve product recycling activities. This deposit system generally consists of two stages. Stage 1 is the provision of a special tax or special rates to a particular product (e.g., beverage bottles). 
Stage 2 is the provision of a special reward for consumers to return the rest of the products for recycling.

The use of government subsidies as an economic instrument of waste management can be used in almost every phase of waste management. For example, in the United States, federal government subsidies are used for planning waste management, resource conservation, and resource recovery.

\section{Research methods}

\subsection{Tipping fee determination}

Tipping fees can be estimated through the income and expenditure approach (IEA) and the limited resource approach (LRA). Meanwhile, the waste fee in Depok, as stated in Depok's Regional Regulation No. 5 of 2012 [8], is based upon waste/hygiene services organised by the city.

The following is the formula for calculating the tipping fee with IEA:

Where:

$$
T=\frac{X_{1}+X_{2}+X_{3}+X_{4}}{S}
$$

$$
\begin{aligned}
& X_{1}=(T P \times G)+(T M \times B)+P \\
& X_{2}=[(T P \times G)+(T M \times B)+P] \times N \\
& X_{3}=(T P \times G)+(T M \times B)+C S+P \\
& X_{4}=(T P \times G)+B O
\end{aligned}
$$

Tipping fee rate $(T)$ in Equation 2 is the division between the sum of the cost of transporting waste $\left(X_{1}\right)$, the cost of managing a temporary processing unit, UPS, $\left(X_{2}\right)$, the cost of landfill management $\left(X_{3}\right)$, the total cost of managing waste served $\left(X_{4}\right)$, and the total waste managed $(S)$. Furthermore, the cost of transportation $\left(X_{I}\right)$ is the sum of the total workers $(T P)$ multiplied by their salary $(G)$ and the total number of vehicles $(T M)$ used multiplied by the cost of operations $(B)$ of the engine/vehicle and the maintenance costs of transporting waste facility $(P)$. UPS management fee $\left(X_{2}\right)$ is the sum of the total workers $(T P)$ multiplied by their salary $(G)$ and the total number of vehicles $(T M)$ used multiplied by the cost of operations $(B)$ of the engine/vehicle and the cost of treatment $(P)$. Then, the sum is multiplied by the number of existing UPS $(N)$. The cost of landfill management $\left(X_{3}\right)$ is the sum of the total workers $(T P)$ multiplied by their salary $(G)$ and the total engine/vehicle $(T M)$ used multiplied by the cost of operations $(B)$ of the engine/vehicle and plus the cost to cover soil $(C S)$ and maintenance cost $(P)$. Landfill bioreactor management cost $\left(X_{4}\right)$ is the sum of the total workers $(T P)$ multiplied by their salary $(G)$ and the operational cost of the bioreactor $(B O)$, which includes the cost of power generation, leachate operation, gas pipeline operation, flare operation, and blower operation.

As mentioned at the beginning, the determination of tipping fee can also be done by the optimal rate of LRA [9]. Limited and non-renewable resources in this study are the waste used to generate electricity. The calculation of waste levy rates with this approach was done by adding the present value of bioreactor plant (PLTSa) management with the total cost of waste management. The formula for the fee is calculated using Equation 7. 


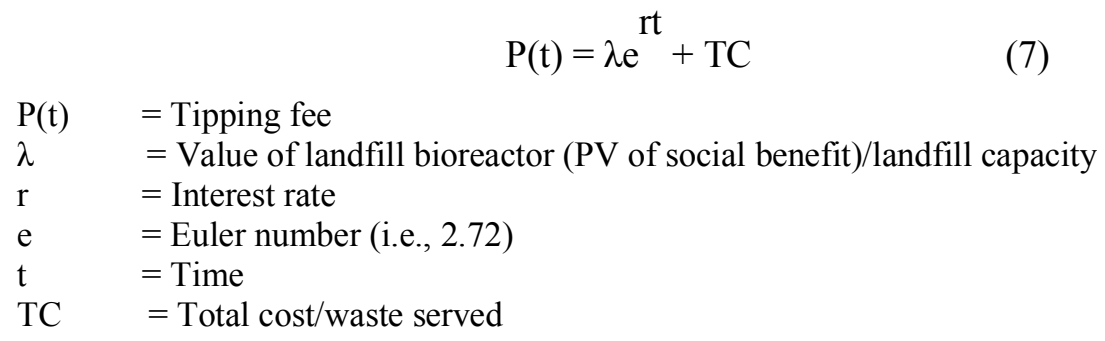

Variable $\lambda$ represents the value of a landfill bioreactor, which is equal to the present value of social benefit of the landfill bioreactor. PV of social benefit is the sum of the project's internal and external benefits to the community. TC is a formula similar to Equation 2.

\subsection{Input data}

The data used in this study include waste management cost, landfill bioreactor investment and operational costs, amount of waste dumped to the landfill, electricity generated, as well as the income obtained from electricity sale. The determination of the tipping fee was carried out using two approaches through Equations 2 - 7.

The tipping fee was calculated with three scenarios: calculation of the existing waste management with cost and income approach (scenario 1), calculation with IAE method with a landfill bioreactor (scenario 2), and calculation with LRA method with a landfill bioreactor (scenario 3). For these purposes, there are several assumptions. It is assumed that the amount of waste increases every 5 years at $88.21 \%$. The assumption is based on the increase in the amount of waste/day in Depok from $2,720 \mathrm{~m}^{3}$ /day in 2010 [3] to 4,534 $\mathrm{m}^{3} /$ day in 2012 [2].

Regarding the increment of the amount of waste and the landfill capacity is assumed to accommodate $8 \%$ of the total waste/year, therefore there is a need to construct 3 new landfills across the span of the project with the costs are assumed to be 1.5 times, 2 times, and 6 times larger than the operational cost of the current landfill at Cipayung. The construction of the new landfills is performed in the $6^{\text {th }}, 11^{\text {th }}$, and $16^{\text {th }}$ year, respectively. The increase of landfill processing capabilities is also followed by the addition of waste transportation capacity, which increases the operational cost at the same rate as the landfill cost. Operational cost at the intermediate processing facility, UPS, is assumed does not increase. As the capacity of waste management increases, the amount of waste that can be served also increases. Finally, it is assumed that the general cost increases every 5 years by $26 \%$. This assumption is based on the inflation rate from 2008-2013. The inflation rate data are taken from the central bank, Bank Indonesia data.

The cost of transporting waste is $36,469,854,000$ IDR/year, whereas the cost of managing the UPS and the landfill reaches $11,655,762,000$ and 4,262,508,875 IDR/year, respectively.

The location of the bioreactor is in Cipayung, Depok. Based on the PLTSa officer's information, Cipayung landfill is estimated to receive 81.6 tonnes of waste/year. Cipayung landfill has three waste pools: pool A, B, and C. Pool B is currently an inactive pool and was closed due to its capacity fulfilment. In this study, the waste at pool B was used as a 
source of electricity. The estimation of methane generation was done using software LandGem V-302 provided by the US EPA. Energy conversion of methane gas into electricity is based on [9], where $1 \mathrm{~m}^{3}$ of methane gas is equivalent to $9.39 \mathrm{kWh}$ of electricity. The electricity generated from this project in the first year reaches 16.93 MW and decreases to $0.05 \mathrm{MW}$ in the $20^{\text {th }}$ year. In the first two years of operation, the landfill capacity is $10 \mathrm{MW}$ whereas the actual electricity produced is greater than $10 \mathrm{MW}$. Based on the EPA recommendation, the maximum capacity of PLTSa is the average of the first five years of its electricity generation.

The electricity generated is sold to a state-owned electricity company, PLN, at the rate of $1,450 \mathrm{IDR} / \mathrm{kWh}$ [11]. Electricity sales tariff is assumed to increase by $18 \%$ for four years. This value is based on the electricity price from 2006-2010 [12]. Clean development mechanism (CDM) is also used as a source of income. Through CDM, each tonne of carbon savings is worth $€ 0.47$ or 7,430 IDR.

The costs for investment as well as operation and maintenance of a landfill bioreactor were taken from LFG Project Development Handbook published by [6]. The investment cost reaches 97,528,987,445 IDR, which includes the installation of a gas collection and flaring system, installation of a condenser, installation of an electricity generator (320 GS Jenbacher Gas Engines), capping, and the installation of gas pipes. Landfill bioreactor operational cost in year 1 is 22,592,700,000 IDR. These costs include the costs of gas pipelines, flares, blowers, power generation, leachate processing, and operator salary. It should be noted that as a result of different methane output each year, the generation of electricity cost is constantly changing based on the basic cost of 2,059,200 IDR/kW.

\section{Results and discussion}

The tipping fee (in IDR/tonne) obtained for each three scenarios and the special tipping fee for households are summarised in Tables 1 and 2 .

In Table 1, it can be seen that the ideal tipping fee for the current condition is 97,704 IDR/tonne. This rate is 15 times larger than the current existing tipping fee, which is 6,448 IDR/tonne. In scenario 2 using IEA, the tipping fee for the first year is 40,032 IDR/tonne. This result is around six times larger than the existing fee. The value is lower than scenario 1 as the revenue comes from electricity sale and carbon saved. In scenario 2, it is seen that the tipping fee gradually increases due to the decreasing electricity production. Even in the $20^{\text {th }}$ year, the tipping fee reaches 144,311 IDR/tonne, which is higher than the tipping fee in scenario 1. In scenario 3using LRA, in the first year of the landfill bioreactor, the user fee is 63.377 IDR/tonne. In this scenario, the tipping fee gradually increases until the $20^{\text {th }}$ year when it reaches $372.488 \mathrm{IDR} /$ tonne because the available resources are limited.

Table 2 shows the results of calculation for the household tipping fee. A1-A5 and B1B5 categories account for non-real estate and real estate categories, respectively. The table clearly shows that all non-real estate fees are not feasible or lower than the ideal rates stated in Table 1. Regarding the very low real estate fee results, the deviation might be due to the fact that the method omits factors such as income, education, and cross-subsidies. 
Table1. Tipping fee calculation results.

\begin{tabular}{|r|r|r|r|r|}
\hline Year & $\begin{array}{c}\text { Scenario 1 } \\
\text { (IDR/tonne) }\end{array}$ & $\begin{array}{c}\text { Scenario 2 } \\
\text { (IDR/tonne) }\end{array}$ & $\begin{array}{c}\text { Scenario 3 } \\
\text { (IDR/tonne) }\end{array}$ & $\begin{array}{c}\text { Current Fee } \\
\text { (IDR/tonne) }\end{array}$ \\
\hline 1 & $97,704.25$ & $40,032.46$ & $63,337.74$ & $6,488.10$ \\
\hline 2 & $97,704.25$ & $40,155.19$ & $66,433.81$ & $6,488.10$ \\
\hline 3 & $97,704.25$ & $45,118.25$ & $74,749.56$ & $6,488.10$ \\
\hline 4 & $97,704.25$ & $59,922.76$ & $93,334.50$ & $6,488.10$ \\
\hline 5 & $97,704.25$ & $61,953.72$ & $99,628.20$ & $6,488.10$ \\
\hline 6 & $116,266.26$ & $105,256.16$ & $147,737.24$ & $8,175.00$ \\
\hline 7 & $16,266.26$ & $108,807.12$ & $56,708.04$ & $8,175.00$ \\
\hline 8 & $16,266.26$ & $111,424.61$ & $65,436.85$ & $8,175.00$ \\
\hline 9 & $16,266.26$ & $111,710.04$ & $72,613.28$ & $8,175.00$ \\
\hline 10 & $16,266.26$ & $113,564.42$ & $182,237.85$ & $8,175.00$ \\
\hline 11 & $111,882.96$ & $111,803.58$ & $89,238.52$ & $10,300.50$ \\
\hline 12 & $11,882.96$ & $112,264.06$ & $99,578.33$ & $10,300.50$ \\
\hline 13 & $11,882.96$ & $112,299.19$ & $10,753.23$ & $10,300.50$ \\
\hline 14 & $11,882.96$ & $112,629.39$ & $23,644.42$ & $10,300.50$ \\
\hline 15 & $111,882.96$ & $112,872.78$ & $38,051.37$ & $10,300.50$ \\
\hline 16 & $43,281.08$ & $144,174.83$ & $85,324.00$ & $12,978.63$ \\
\hline 17 & $143,281.08$ & $144,177.86$ & $03,335.18$ & $12,978.63$ \\
\hline 18 & $143,281.08$ & $144,236.43$ & $23,699.40$ & $12,978.63$ \\
\hline 19 & $43,281.08$ & $144,279.59$ & $46,638.87$ & $12,978.63$ \\
\hline 20 & $43,281.08$ & $144,311.41$ & $72,488.17$ & $12,978.63$ \\
\hline & & & & \\
\hline
\end{tabular}

Table 2.Tipping fee for household category.

\begin{tabular}{|c|c|c|c|c|}
\hline Category & $\begin{array}{c}\text { Scenario 1 } \\
\text { (IDR/mo) }\end{array}$ & $\begin{array}{c}\text { Scenario 2 } \\
\text { (IDR/mo) }\end{array}$ & $\begin{array}{c}\text { Scenario 3 } \\
\text { (IDR/mo) }\end{array}$ & $\begin{array}{c}\text { Current Fee } \\
\text { (IDR/mo) }\end{array}$ \\
\hline A1 & $4,836.36$ & $1,981.61$ & $3,135.22$ & 4,000 \\
\hline A2 & $9,672.72$ & $3,963.21$ & $6,270.44$ & 7,000 \\
\hline A3 & $21,763.62$ & $8,917.23$ & $14,108.48$ & 9,000 \\
\hline A4 & $38,690.88$ & $15,852.85$ & $25,081.75$ & 12,000 \\
\hline A5 & $53,199.97$ & $21,797.68$ & $34,487.40$ & 17,000 \\
\hline B1 & $4,836.36$ & $1,981.61$ & $3,135.22$ & 14,000 \\
\hline B2 & $9,672.72$ & $3,963.21$ & $6,270.44$ & 17,000 \\
\hline B3 & $14,509.08$ & $5,944.82$ & $9,405.65$ & 20,000 \\
\hline B4 & $21,763.62$ & $8,917.23$ & $14,108.48$ & 25,000 \\
\hline B5 & $29,018.16$ & $11,889.64$ & $18,811.31$ & 35,000 \\
\hline
\end{tabular}




\section{Conclusion}

Based on the calculation results, the appropriate tipping fees for the city of Depok are $97,704,40,032$, and 63,337 IDR/tonne according to the cost and income approach, IAE method, and LRA method, respectively. All calculations are higher than the existing fee of6,488 IDR/tonne. This might be the reason that the waste service level of the city of Depok is low. The application of a landfill bioreactor can reduce the amount of fees needed for both scenarios 2 and 3. In the first year of operation, the tipping fees will be reduced by $55 \%$ and $30 \%$, respectively.

This work was supported partially by PITTA 2018 Grant funded by DRPM Universitas Indonesia under contract No. 2437/UN2.R3.1/HKP.05.00/2018.

\section{References}

1. Kementrian Lingkungan Hidup, Status Lingkungan Hidup Indonesia 2012. Jakarta: Kementrian Lingkungan Hidup (2012). In Bahasa Indonesia.

2. Badan Pusat Statistik, Kota Depok DalamAngka 2012. Jakarta: Badan Pusat Statistik. (2012). In Bahasa Indonesia

3. M. Handono, Model Tempat Pemrosesan Akhir (TPA) Secara Berkelanjutan Di TPA Cipayung Kota Depok Jawa Barat. Institut Pertanian Bogor, Bogor (2010). Unprinted doctoral dissertation. In Bahsa Indonesia

4. Sudrajat, Mengelola Sampah Kota. Jakarta: Penabur Swadaya. (2006).

5. G. Tchobanoglous, R. Eliassen, H. Theisen, Solid Waste Engineering Principles and Management Issues. Tokyo: McGraw-Hill Kogakusha. (1977).

6. US EPA, United States Environmental Protection Agency, Landfill Gas Energy Project Development Handbook. Landfill Methane Outreach. Program (LMOP), Climate Change Division, U.S. EPA. Washington, D.C: US EPA. (2010).

7. United Nations Environmental Programme, Solid Waste Management. Nairobi: United Nations Environmental Programme. (2005).

8. Pemerintah Kota Depok. Peraturan Daerah Kota Depok Nomor 5 Tahun 2012 Tentang Retribusi Pelayanan Persampahan atau Kebersihan. Depok: Pemerintah Kota Depok (2012). In Bahasa Indonesia

9. M. Ready, J. Environ. Econ. Manag. 28, 307-323. (1995).

10. B. Sorensen, Renewable Energy Conversion, Transmision, and Storage. Massachusetts: Academic Press. (2007).

11. Kementrian Energi dan Sumber Daya Mineral, Peraturan Menteri Energi dan Sumber Daya Mineral Nomor 4 Tahun 2012 Tentang Harga Pembelian Tenaga Listrik Oleh PT. PLN (Persero) Dari Pembangkit Tenaga Listrik yang Menggunakan Energi Baru Terbarukan Skala Kecil dan Menengah atau Kelebihan Tenaga Listrik. KESDM (2012). In Bahasa Indonesia

12. H. Prasetyo, Analisis Kebijakan Pembatasan Kenaikan Tarif Tenaga Listrik Untuk Industri dari Perspektif Hukum Persaingan Usaha. Unprinted master thesis, Universitas Indonesia, Depok. (2011). In Bahasa Indonesia 